\author{
José Manuel M. BOTELHO, \\ Iveta MIETULE, \\ Serhii HUSHKO, \\ Volodymyr KULISHOV, \\ Irina MAKSYMOVA
}

\title{
COMPARATIVE ADVANTAGES \\ OF INTERNATIONAL TRADE: \\ THE BILATERAL OPPORTUNITIES \\ PORTUGAL - LATVIA, PORTUGAL - POLAND \\ AND PORTUGAL - UKRAINE
}

\begin{abstract}
The paper aims to estimate which sector is under-exploited in terms of the trade between Portugal and three other European countries: Latvia, Poland and

(C) José Manuel M. Botelho, Iveta Mietule, Serhii Hushko, Volodymyr Kulishov, Irina Maksymova, 2021.

Botelho, José Manuel M., PhD, University of Evora, Portugal. ORCID: 0000-0002-4001-6563 Email: jmmbinternationalization@gmail.com.

Mietule, Iveta, Dr.oec., Professor, Faculty of Economics and Management, Rezekne Academy of Technologies, Latvia. ORCID: 0000-0001-7662-9866 Email: mietule@inbox.Iv.

Hushko, Serhii, Dr.oec., Professor, State University of Economics and Technology, Ukraine. ORCID: 00000002-4833-3694 Email: vice-rector@duet.edu.ua.

Kulishov, Volodymyr, Dr.oec., Professor, Department of International Economics, State University of Economics and Technology, Ukraine. ORCID: 0000-0002-8527-9746 Email: kulishov_vv@kneu.dp.ua.

Maksymova, Irina, PhD, Associate Professor, Department of International Economics, State University of Economics and Technology, Ukraine. ORCID: 0000-0001-9754-0414 Email: maksimova_ii@kneu.dp.ua.
\end{abstract}


94 José Manuel M. Botelho, Iveta Mietule, Serhii Hushko, Volodymyr Kulishov, Irina Maksymova

Comparative advantages of international trade: the bilateral opportunities

Portugal - Latvia, Portugal - Poland and Portugal - Ukraine

Ukraine. The Feitoria Model identifies underexploited sector/products for the selected markets in order to increase their exportations. The Feitoria Model is based on the comparative advantage concept of Ricardo with the incorporation of economic, political and competitiveness dimensions. The methodology presented in the study is configured comparing the potential trade indicators to effectively verified ones among the countries and uses a trade database of 2014-2018 period extracted from the United Nations Comtrade free database (UN Comtrade International Trade Statistics Database).

\section{Key words:}

comparative advantages; Feitoria Model; index of complementarity; index of commerce effectiveness; international trade.

JEL: F10, F11, F17.

13 Tables, 2 Formulae, 30 References.

\section{Introduction}

If there is a point on which most economists agree, it is that trade among nations makes the world better off. When a firm or an individual buys a good or a service produced more cheaply abroad, living standards in both countries increase. There are other reasons consumers and firms buy abroad that also make them better off - the product may better fit their needs than similar domestic offerings or it may not be available domestically. In any case, the foreign producer also benefits by making more sales than it could selling solely in its own market and by earning foreign exchange (currency) that can be used by themselves or others in the country to purchase foreign-made products (McDonald, 2020).

The theories of international trade consolidate the idea that there are gains when different regions are related - a developed export sector is capable of making strong impact on the generation of jobs and income, as well as on the distri- 
bution of wealth in the population. On the import side, it is possible to generate welfare gains when a greater variety of products are available to be consumed; with regard to international relations in the financial system and in the flow of labor, it facilitates the entry of valuable productive resources into the country (Xavier, 2009). As Galvão (2000) explains, international trade ceased to be a simple possibility of exporting productive surpluses; nowadays it has an important role for growth and for the improvement of economic well-being.

The aim of this study is to estimate the underexploited products for the trade between Portugal and Latvia, Poland and Ukraine. The estimation is based on The Feitoria Model developed by Botelho \& Kulishov in 2018 and improved by Botelho \& Kulishov in 2019 with the introduction of the Most Favoured Nation Tariff (MFN Tariff).

According to European Commission (2020a), "Small and medium-sized enterprises (SMEs) are the backbone of Europe's economy. They represent $99 \%$ of all businesses in the EU. They employ around 100 million people, account for more than half of Europe's GDP and play a key role in adding value in every sector of the economy (Estrin et al., 2017). SMEs bring innovative solutions to challenges like climate change, resource efficiency and social cohesion and help spread this innovation throughout Europe's regions (Rehm \& Goel, 2017). They are therefore central to the EU's twin transitions to a sustainable and digital economy. They are essential to Europe's competitiveness and prosperity, industrial ecosystems, economic and technological sovereignty, and resilience to external shocks». One of the ways of remaining competitive, achieving a long-term profitability, competitive success, and actually surviving lies in the internationalization process, not only for SMEs but also for large enterprises (Kubíčkováa et al. 2014).

Some of the reasons behind the popularity of internationalization among current companies include opening up of trade borders by most countries across the world and elimination of trade barriers among many others. Companies are no longer secure staying in the domestic market and therefore most companies tend to go for internationalization to be able to spread their risks (Ricard et al., 2020). Internationalization has become much easier due to the communication and technological advancement (Azuayi, 2014).

Exporting often represents an initial step for the internationalization of a firm that normally does not need a physical presence in the host market (Malhotra \& Hinings, 2010). Thus, the nonlinear internationalization of exporting activities becomes a particularly viable process (Bernini et al., 2016).

Finding an underexploited market or product is not an easy task. In order to achieve this objective, the Feitoria Model developed by Botelho \& Kulishov in 2018 and upgraded by Botelho \& Kulishov in 2019 is suggested. 


\section{Literature Review}

The comparative advantage concept, proposed by Ricardo (1817), is one of the most used models both in the classical and neoclassical theories. According to Ricardo's theory, a country will benefit if it specializes in the production of goods whose manufacture is intensive in its abundant resources. Thus, in developing countries where the reserve labor force is very large owing to open or disguised unemployment (Myrdal, 1956; Prebisch, 1959), best results can be achieved by specializing in the production of labor-intensive goods.

Vaillant \& Ons (2003), Xavier et al. (2008) and Xavier (2009), use the comparative advantage of the exporter and comparative disadvantage of the importer crossed, through the so-called Index of Complementarity (IC) in conjugation with the Index of Effectiveness Commerce (EC), with the aim of confronting the potential trade of two regions against what was actually observed in a given period.

The Feitoria Model was created by Botelho \& Kulishov in 2018, regarding the bilateral trade opportunities between Portugal and Poland base on the 20122016 trade database. In 2019, the Feitoria Model was upgraded by Botelho \& Kulishov through the introduction of the concept of competitiveness of products in markets using the Most-Favored Nation Tariff (MFN Tariff). The bilateral trade opportunities between Portugal and Poland were recalculated and Ukraine was added into the analysis based on the 2013-2017 trade database.

In this paper, authors estimate the underexploited products for three European countries; recalculate the underexploited products for Poland and Ukraine and add Latvia into the analysis based on the 2014-2018 trade database.

\section{Macroeconomic Outlook}

It is fundamental to know the economic outlook of each country in order to study and decide the market that has the best economic environment. Therefore, the economic outlook for Latvia, Poland, Portugal and Ukraine is as follows.

Latvia outlook. According to the European Commission (2020b), «...in the first quarter of 2020 , the economy declined by $2.9 \%$ compared to the previous quarter, somewhat less than expected in the spring. Consumption took by far the largest hit as containment measures enacted in the middle of March shut many services down and uncertainty over future incomes made consumers hold back on purchases of durable goods. Exports of services declined substantially 
due to border closures and falling demand. Government consumption picked-up because of increased spending on healthcare.

The drag on consumer activity is estimated to have peaked in April as containment measures have gradually been eased since the start of May. A notable improvement in expectations among key industries together with a resumption of mobility patterns, both in May, further support this view. However, demand from European trading partners appears to be taking longer to recover and as a result, exports may still show a decline in May before resuming growth. Also, the pace of recovery is set to differ significantly across the economy - private investment and exports may still struggle in the third quarter while consumption is forecast to pick up at a brisk pace relatively soon. Public consumption and investment are set to get a boost from the government stimulus package. Overall, GDP is forecast to decline by some $13 \%$ in the first half of 2020 compared to the last quarter of 2019. It is expected to recover rather quickly receiving a particular boost at the end of the year when work begins on the Rail Baltica project, which will integrate the rail systems of the Baltic countries with the rest of the EU. Overall, GDP is projected to contract in 2020 by $7 \%$. In 2021, GDP growth is forecast to exceed $6 \%$.

Inflation is forecast to slow to a near standstill due to declining energy prices and deflationary pressure stemming from a sizeable demand shortfall. Conversely, it should pick up again in 2021 , as demand recovers, led primarily by food and services prices».

Poland outlook. According to the European Commission (2020c), «Poland's economy proved relatively resilient in the first quarter of 2020, mainly due to its low exposure to hard-hit sectors and diversified economic structure. GDP fell by $-0.4 \%$ quarter-on-quarter driven by a significant fall in private consumption, while investment decreased only moderately as the construction sector kept expanding and industrial production recorded just a mild contraction.

GDP is expected to plunge in the second quarter and to gradually recover from then onwards, leaving annual GDP growth at around $-4.5 \%$ in 2020 and $4.25 \%$ in 2021. Despite the government measures put in place, private consumption is likely to suffer in 2020 as consumers accumulate precautionary savings and withhold spending due to social distancing and high uncertainty. Coupled with supply chain disruptions and a fall in orders in March and April, low business confidence will likely have an impact on investment, which is projected to plunge in the second quarter and to recover only partially over the forecast horizon. Furthermore, a fall in demand in Poland's main trading partners will likely take its toll on exports in 2020, especially in the transport and tourism sectors. As the drop in imports is expected to be less pronounced, the trade balance is set to be a drag on growth in 2020.

HICP inflation accelerated significantly at the end of 2019 and the beginning of 2020 , driven by a sustained increase in service and food prices. However, 
98 José Manuel M. Botelho, Iveta Mietule, Serhii Hushko, Volodymyr Kulishov, Irina Maksymova

Comparative advantages of international trade: the bilateral opportunities Portugal - Latvia, Portugal - Poland and Portugal - Ukraine

slower wage growth and weak demand caused by the COVID-19 pandemic is set to put an end to a nearly two-year-long trend of uninterrupted increases in service price inflation, which is expected to drop in the second half of 2020 and early 2021. Moreover, a significant fall in oil prices in the first four months of the year is likely to bring energy prices down in 2020. As a result, HICP inflation is expected to average $2.7 \%$ y-o-y in 2020 and to reach $2.8 \%$ in 2021 as economic activity recovers».

Portugal outlook. According to OECD (2020), «the economy is projected to shrink by $11.3 \%$ in 2020 , should a second pandemic outbreak hit at the end of 2020 (the double-hit scenario). Assuming a single wave of the pandemic (the single-hit scenario), GDP is expected to decline by $9.4 \%$ in 2020 , with a rebound of $6.3 \%$ in 2021 . In the double-hit scenario, the recovery will be slower due to prolonged export weaknesses, heightened uncertainty, additional bankruptcies, and prolonged unemployment spells. By the end of 2021, public debt (Maastricht definition) is expected to increase to $131 \%$ of GDP if the virus outbreak subsides by this summer and $138 \%$ of GDP if there is a second wave later this year. The government has implemented a number of measures to support firms and households and announced further measures to revamp the economy after the general confinement. The short-term work scheme is containing the rise in unemployment. Tax and social security contribution deferrals alongside credit guarantees provide financial support to companies. The central bank provides ample liquidity along with eased macro-prudential rules. If the crisis wears on, additional measures need to be considered. Debt reduction policies can help firms remain viable in the long term. Further revamping out-of-court insolvency processes could speed up debt resolution in case of substantial loan foreclosures.

Strong macroeconomic policies should be sustained. Pushing forward with the multi-year fiscal consolidation effort would help reduce vulnerabilities. In the event of a material downturn, a neutral fiscal stance would be appropriate, allowing the nominal deficit to widen as automatic stabilizers operate, as long as the public debt ratio remains on a downward trajectory. Supervisors should ensure that banks follow through with their NPL reduction targets and strengthen their corporate governance, internal controls, and risk management. Strengthening domestic saving rates is necessary to continue deleveraging and sustain higher investment rates without creating new external imbalances. The authorities should consider steps to encourage complementary second- and third-pillar pension schemes to boost private saving".

Ukraine outlook. According to the World Bank (2020b), «The economy is expected to contract by 5.5 percent in 2020 , as weakness in the first half of the year is only partly offset by a recovery in domestic demand in the second half and positive contributions from net exports. The baseline assumes a possible reimposition of containment measures in response to a "second wave" (given that daily reported infections are still increasing) and a slower pace of reforms. Ukraine still expects to raise US\$2.9 billion in additional official financing (from 
the IMF, World Bank, and EU) in the remainder of the year. If these funds are delayed, the government will have to contain spending or borrow more domestically.

Going forward, growth is expected to remain modest at 1.5 percent in 2021 , rising to about 3.7 percent by 2023 . The outlook depends on the duration of the health crisis and reforms that address bottlenecks to investment and safeguard macroeconomic sustainability. With the recent loss of reform momentum, fixed investment is expected to reach its pre-crisis level only at the end of 2022, and net exports (as import demand revives but the pace of export diversification remains slow) will continue to be a drag on growth in 2021. Poverty based on the international US $\$ 5.5$ a day poverty line is low in Ukraine and is expected to increase by 0.2 percentage points in 2020. At higher thresholds, the poverty increase will be larger, with poverty based on the World Bank's national poverty line for Ukraine expected to increase by 2 percentage points. Sustainable economic growth is needed to reduce poverty rates in the medium term».

Governance case. The Feitoria Model incorporates economic and political concepts such as the Ease of Doing Business (World Bank, 2020a), Worldwide Governance Indicators (2020), the Credit Rating and the Free Commerce.

According to World Bank's (2020a) the Ease of Doing Business, economies are ranked on their ease of doing business from 1-190. A high ease of doing business ranking means the regulatory environment is more conducive to the starting and operation of a local firm. The rankings are determined by sorting the aggregate distance to frontier scores on 10 topics, each consisting of several indicators, giving equal weight to each topic. In Doing Business 2020, Latvia is the $19^{\text {th }}$ country $\left(2019: 19^{\text {th }}\right)$, Poland is the $40^{\text {th }}$ country $\left(2019: 33^{\text {th }}\right)$ and Portugal is the $39^{\text {th }}\left(2019: 34^{\text {th }}\right)$ (World Bank, 2020a).

Worldwide Governance Indicators (2020) project reports aggregate and individual governance indicators for over 200 countries and territories over the period of 1996-2019 for six dimensions of governance: Voice and Accountability, Political Stability and Absence of Violence, Government Effectiveness, Regulatory Quality, Rule of Law, Control of Corruption. The position of each country in this work is presented in Table 1.

The Credit Rating of Standard \& Poors (2020): For S\&P, a bond is considered investment grade if its credit rating is $\mathrm{BBB}-$ or higher. Bonds rated $\mathrm{BB}+$ and below are considered to be speculative grade, sometimes also referred to as «junk» bonds. In December/2020 Latvia had «A+», Poland «A-», Portugal had «BBB» and Ukraine had «B» ratings.

The free commerce is an indicator in Feitoria Model that characterizes restrictions on imports or exports due to any kind of embargo - political, religious or other. In practice if there is any import or export restriction, the product is elected not to be selected as an opportunity. 
100 José Manuel M. Botelho, Iveta Mietule, Serhii Hushko, Volodymyr Kulishov, Irina Maksymova

Comparative advantages of international trade: the bilateral opportunities Portugal - Latvia, Portugal - Poland and Portugal - Ukraine

Table 1

Worldwide Governance Indicators

\begin{tabular}{|l|c|c|c|c|}
\hline \multirow{2}{*}{\multicolumn{1}{|c|}{ Dimension }} & \multicolumn{4}{c|}{ Position 2019 } \\
\cline { 2 - 5 } & Latvia & Poland & Portugal & Ukraine \\
\hline Voice and Accountability & 53 & 60 & 23 & 106 \\
\hline $\begin{array}{l}\text { Political Stability and Absence } \\
\text { of Violence/Terrorism }\end{array}$ & 85 & 76 & 20 & 193 \\
\hline Government Effectiveness & 35 & 57 & 34 & 126 \\
\hline Regulatory Quality & 35 & 40 & 47 & 121 \\
\hline Rule of Law & 41 & 71 & 33 & 156 \\
\hline Control of Corruption & 67 & 61 & 48 & 154 \\
\hline
\end{tabular}

Source: compiled by the authors using the data of Worldwide Governance Indicators (2020).

\section{Methodology}

The underexploited products for the bilateral trade between Portugal and three other European countries, Latvia, Poland and Ukraine are identified by the Feitoria Model. In order to determine the underexploited products, the model determines the comparative advantage of each product in each country by using two indexes. The first one is the Index of Effective Commerce (EC), which compares the potential trade of two countries against what was actually observed in a given period (Vaillant \& Ons, 2003). The second one is the Index of Complementarity (IC), which analyses the crossover between supply and demand for the studied products taking into account the world context, that is, the comparative advantages of the exporter and the comparative disadvantages of the importer (Xavier et al., 2008; Xavier, 2009).

According Botelho \& Kulishov $(2018,2019)$, after selecting a new market (country) based on EC and IC indexes and other variables of the Feitoria Model, the next step is to study the selected markets in order to choose the country with the best macroeconomic situation. The economic situation warns about economic risks that could inflict severe and long-lasting damage on development prospects. The Gross Domestic Product (GDP) growth included in economic outlook provides an economic snapshot of a country, used to estimate the size of an economy and growth rate. The GDP growth leads to a more competitive economy. GDP growth is in fact an outcome of competitiveness and the level of competitiveness of a country is determined by the way the resources and competencies are managed. Therefore, countries are interested in increasing the competi- 
tiveness to attract business investments and, therefore, it is fundamentally important to know the economic outlook of the country.

Index of Complementarity (IC) is used to identify trade potential. The indicator analyzes crossover between supply and demand for the studied products, taking into account the world context, that is, the comparative advantages of the exporter and the comparative disadvantages of the importer (Xavier et al., 2008 and Xavier, 2009). The indicator is as follows:

$$
I C_{i j}^{s}=\left(\frac{\frac{X_{i W}^{s}}{\sum_{s} X_{i W}^{s}}}{\frac{X_{W W}^{s}}{\sum_{s} X_{W W}^{s}}}\right) \cdot\left(\frac{M_{j W}^{s}}{\sum_{s}^{s} M_{j w}^{s}}\right)=\frac{\frac{X_{i W}^{s}}{\sum_{s}^{s} X_{i W}^{s}} \cdot \frac{M_{j W}^{s}}{\sum_{s}^{s} M_{j W}^{s}}}{\left(\frac{M_{W W}^{s}}{\sum_{s} M_{W W}^{s}}\right)^{2}}
$$

where: $i$, exporting region; $j$, importing region; $W$, all regions of the world; $s$, sector considered in the analysis; $X_{i w}^{s}$, exports, for each sector $s$, from $i$ to the world; $\sum_{s} X_{i W}^{s}$, total exports from $i$ to the world; $M_{j W}^{s}$, imports, for each sector $s$, from $j$ of the world ; $\sum_{s} M_{j W}^{s}$, total imports from $j$ of the world; $M_{W W}^{s}$, total world imports, for each sector $s ; \sum_{s} M_{W W}^{s}$, total world imports.

When $I C>1$, there is complementarity between $i$ and $j$; below this value, there isn't trade potential between the two.

In order to compare the results of complementarity to the trade actually carried out between two partners, the Index of Effective Commerce (EC) is used (Xavier et al., 2008 and Xavier, 2009).

$$
\left.E C_{i j}^{s}=\left(\frac{\frac{X_{i j}^{s}}{\sum_{s} X_{i j}^{s}}}{\frac{X_{i W}^{s}}{\sum_{s} X_{i W}^{s}}}\right) \cdot\left(\frac{\sum_{s}^{s} M_{j i}^{s}}{M_{j W}^{s}}\right)=\frac{\left(\frac{X_{i j}^{s}}{\sum_{s} X_{i j}^{s}}\right)^{2}}{\sum_{s} M_{j W}^{s}}\right) \frac{X_{i W}^{s}}{\sum_{s} X_{i W}^{s}} \cdot \frac{M_{j W}^{s}}{\sum_{s} M_{j W}^{s}}
$$


where: $i$, exporting region; $j$, importing region; $W$, all regions of the world; $s$, sector considered in the analysis; $X_{i j}^{S}$, exports, for each sector $s$, from $i$ to $j ; \sum_{s} X_{i j}^{s}$, total exports from $i$ to $j ; M_{j i}^{s}$, imports, for each sector $s$, of $j$ from $i ; \sum_{s} M_{j i}^{s}$, total imports of $j$ from $i ; X_{i W}^{s}$, exports, for each sector $s$, from $i$ to the world; $\sum_{s} X_{i W}^{s}$, total exports from $i$ to world; $M_{j w}^{s}$, imports, for each sector $\mathrm{s}$, of $j$ from the world; $\sum_{s} M_{j W}^{s}$, total imports of $j$ from the world.

According Xavier et al. (2008) and Xavier (2009), for a given sector $s$, if the value of EC is greater (smaller) than the unity, then the effective trade from $i$ to $j$ would be beyond (below) the average expectations; and for a given sector $\mathrm{s}$, if the value of $E C$ is equal to the unity, then the effective trade from $i$ to $j$ would only reflect the average expectations.

According to Xavier et al. (2008) and Xavier (2009), the main use of this index is the comparison with the Index of Complementarity (IC). For a given sector $s$, it is expected that the result of EC>1 is compatible with the existence of complementarity between regions $i$ and $j(\mathrm{IC}>1)$. On the other hand, it is also expected that, for given sector $s$, the result of $E C<1$ is compatible with the absence of complementarity between $i$ and $j(\mathrm{IC}<1)$.

According to Xavier et al. (2008) and Xavier (2009), when EC $>1$ and $I C<1$, it means that, exceeding average expectations in an environment of noncomplementarity between $i$ and $j$, the sector $s$ showed a trade surplus. On the other hand, if $\mathrm{EC}<1$ and $\mathrm{IC}>1$ there is complementarity between $i$ and $j$ but the sector $s$ should demonstrate better commercial performance, which was not observed. Therefore, the sectors with opportunities to exploit have IC $>1$ and $E C<1$, that is, these sectors do not take advantage of the complementarity existing between $i$ and $j$. The identification of these opportunities is the main objective of this article.

The combination of the Index of Complementarity (IC) and the Index of Effective Commerce (EC) indicates underexploited sectors in trade relations between two markets (countries/regions). Index of Complementarity (IC) evaluates the existing potential. If $I C>1$, the two markets (countries/regions) studied would be complementary, that is, the two markets (countries/regions) have potential for trade relations. The Index of Effective Commerce (EC) indicates the effectiveness of trade: first the potential sectors are selected, those with index IC $>1$, and then, among the potential sectors, those with $\mathrm{EC}<1$ are eliminated, as they would not have effective trade (Xavier et al., 2008; Xavier, 2009). 
According to Botelho \& Kulishov $(2018,2019)$, the Feitoria Model incorporates Fundamental Concepts: the comparative advantage concept, the size (amount of trade) and the dynamism (given by growth of trade, expressed by CAGR - Compound Annual Growth Rate) and Economic and Political Concepts: the Ease of Doing Business, Worldwide Governance Indicators, the Credit Rating, the Free Commerce and the Competitiveness Concept MFN Tariff (MostFavored Nation Tariff).

The Feitoria Model incorporates an important concept - the MFN Tariff. MFN tariffs are what countries promise to impose on imports from other members of the World Trade Organization, unless the country is part of a preferential trade agreement (such as a free trade area or customs union). This means that, in practice, MFN rates are the highest (most restrictive) rates that WTO members charge one another (World Integrated Trade Solution, 2020).

Successive rounds of multilateral trade negotiations since 1947 have helped achieve significant reductions in import duties. This is particularly true for industrial goods, on which tariffs have fallen from around $40 \%$ at the end of World War II to a tenth of that today. They also alter the relative prices of products, and can protect uncompetitive companies and their overpriced products. These distortions are particularly pronounced in many non-OECD countries where tariffs remain substantially higher than in the OECD area (Love \& Lattimore, 2009).

\section{Bilateral Trade Data Overview}

The trade database refers to 2014-2018 and it uses the Harmonized System (HS four-digit code). The structure of HS therefore comprises 97 chapters which, in turn, can be disaggregated into 1,254 four-digit levels - for example, Chapter 01 can be disaggregated into six subsectors, which are characterized in codes from 0101 to 0106 , Chapter 02 can be disaggregated into ten subsectors, which are characterized in codes from 0201 to 0210 . Harmonized Commodity Description and Coding Systems (HS) is an international nomenclature for the classification of products. It allows participating countries to classify traded goods on a common basis for customs purposes. At the international level, the Harmonized System (HS) for classifying goods is a six-digit code system. The HS comprises approximately 5,300 article/product descriptions that appear as headings and subheadings, arranged in 99 chapters, grouped in 21 sections. The six digits can be broken down into three parts. The first two digits (HS-2) identify the chapter the goods are classified in, e.g. 09 = Coffee, Tea, Maté and Spices. The next two digits (HS-4) identify groupings within that chapter, e.g. $09.02=$ Tea, whether or not flavoured. The next two digits (HS-6) are even more specific, e.g. 09.02.10 Green tea (not fermented). Up to the HS-6 digit level, all countries classify products in the same way (a few exceptions exist where some countries apply old versions of the HS). 
104 José Manuel M. Botelho, Iveta Mietule, Serhii Hushko, Volodymyr Kulishov, Irina Maksymova

Comparative advantages of international trade: the bilateral opportunities

Portugal - Latvia, Portugal - Poland and Portugal - Ukraine

The bilateral trade overview based on HS-4 products between Portugal and the three European countries Latvia, Poland and Ukraine is as follows.

Portugal - Latvia. Latvia reestablished its independence in 1991 following the breakup of the Soviet Union. The commercial relations between Portugal and Latvia increased significantly since Latvia integrated into the European Union in 2004. In 2006, the bilateral trade between Portugal and Latvia was around $€ 29,7$ million and in 2018 it was around $€ 47,1$ million, showing an increase of $58,2 \%$.

In 2018, Portugal exported 236 products to Latvia (of 1,254 products total). Between 2014 and 2018, the exports from Portugal to Latvia had grown 12.5\% to $€ 36.4$ million (more than the exports to the World: 5.5\%). The 10 largest products in value represent $71.6 \%$ of total products exported from Portugal to Latvia. Table 2 presents the Top 10 exported products in value from Portugal to Latvia.

Table 2

Top 10 products in value exported: Portugal to Latvia

\begin{tabular}{|c|c|c|c|c|c|}
\hline Products (HS-4) & $\begin{array}{c}2014 \\
(€ \text { Million) }\end{array}$ & $\begin{array}{c}2018 \\
(€ \text { Million })\end{array}$ & $\begin{array}{c}\text { CAGR }_{14-18} \\
(\%)\end{array}$ & $\begin{array}{l}\text { Rank } \\
2018\end{array}$ & Share \\
\hline TOTAL - All products & 20,2 & 36,4 & $12,5 \%$ & & \\
\hline $\begin{array}{l}8703 \text { - Motor cars and } \\
\text { other motor vehicles } \\
\text { principally designed for } \\
\text { the transport ... }\end{array}$ & 1,1 & 9,5 & $53,4 \%$ & 1 & $25,9 \%$ \\
\hline $\begin{array}{l}4802 \text { - Uncoated paper } \\
\text { and paperboard, of a } \\
\text { kind used for writing, } \\
\text { printing, ... }\end{array}$ & 5,2 & 4,9 & $-1,3 \%$ & 2 & $13,3 \%$ \\
\hline $\begin{array}{l}3901 \text { - Polymers of eth- } \\
\text { ylene, in primary forms }\end{array}$ & 0,0 & 2,2 & n.a. & 3 & $6,0 \%$ \\
\hline $\begin{array}{l}8473 \text { - Parts and ac- } \\
\text { cessories (other than } \\
\text { covers, carrying cases } \\
\text { and the like) ... }\end{array}$ & 0,0 & 2,1 & n.a. & 4 & $5,8 \%$ \\
\hline $\begin{array}{l}8471 \text { - Automatic data- } \\
\text { processing machines } \\
\text { and units thereof; ma- } \\
\text { chines ... }\end{array}$ & 0,7 & 2,0 & $22,4 \%$ & 5 & $5,5 \%$ \\
\hline $\begin{array}{l}2204-\text { Wine of fresh } \\
\text { grapes, incl. fortified } \\
\text { wines; grape must, ... }\end{array}$ & 1,2 & 1,7 & $7,5 \%$ & 6 & $4,6 \%$ \\
\hline
\end{tabular}




\begin{tabular}{|l|c|c|c|c|c|}
\hline \hline Products (HS-4) & $\begin{array}{c}2014 \\
\text { (€ Million) }\end{array}$ & $\begin{array}{c}2018 \\
\text { (€ Million) }\end{array}$ & $\begin{array}{c}\text { CAGR } \\
\text { (\%) }\end{array}$ & $\begin{array}{c}\text { Rank } \\
2018\end{array}$ & Share \\
\hline $\begin{array}{l}\text { 6403 - Footwear with } \\
\text { outer soles of rubber, } \\
\text { plastics, leather .. }\end{array}$ & 0,4 & 1,6 & $33,6 \%$ & 7 & $4,5 \%$ \\
\hline $\begin{array}{l}0706 \text { - Carrots, turnips, } \\
\text { salad beetroot, salsify, } \\
\text { celeriac, radishes ... }\end{array}$ & 0,4 & 1,0 & $20,2 \%$ & 8 & $2,8 \%$ \\
\hline $\begin{array}{l}8517 \text { - Telephone sets, } \\
\text { incl. telephones for cel- } \\
\text { lular networks or for } \\
\text { wireless networks; }\end{array}$ & 0,1 & 0,6 & $46,4 \%$ & 9 & $1,7 \%$ \\
\hline $\begin{array}{l}3004-\text { Medicaments } \\
\text { consisting of mixed or } \\
\text { unmixed products for } \\
\text { therapeutic ... }\end{array}$ & 0,1 & 0,5 & $42,0 \%$ & 10 & $1,4 \%$ \\
\hline
\end{tabular}

Sources: COMTRADE, Feitoria Model

CAGR: Compound Annual Growth Rate; n.a.: not available.

Latvia - Portugal. In 2018, Latvia exported 117 products to Portugal (of 1,254 products total). Between 2014 and 2018, the exports from Latvia to Portugal had grown $12 \%$ to $€ 10.6$ million (more than the exports to the World: $4.2 \%$ ). The 10 largest products in value represent $73.5 \%$ of total products exported from Latvia to Portugal. Table 3 presents the Top 10 exported products in value from Latvia to Portugal.

Table 3

Top 10 products in value exported: Latvia to Portugal

\begin{tabular}{|l|c|c|c|c|c|}
\hline Products (HS-4) & $\begin{array}{c}2014 \\
\text { (€ Million) }\end{array}$ & $\begin{array}{c}2018 \\
\text { (€ Million) }\end{array}$ & $\begin{array}{c}\text { CAGR }_{14-18} \\
(\%)\end{array}$ & $\begin{array}{c}\text { Rank } \\
2018\end{array}$ & Share \\
\hline TOTAL - All products & 6,0 & 10,6 & $12,0 \%$ & & \\
\hline $\begin{array}{l}3102-\text { Mineral or } \\
\text { chemical nitrogenous } \\
\text { fertilisers ... }\end{array}$ & 0,0 & 2,2 & $207,5 \%$ & 1 & $20,7 \%$ \\
\hline $\begin{array}{l}8517-\text { Telephone sets, } \\
\text { incl. telephones for cel- } \\
\text { lular networks; other ... }\end{array}$ & 0,6 & 1,2 & $12,7 \%$ & 2 & $11,0 \%$ \\
\hline
\end{tabular}



Portugal - Latvia, Portugal - Poland and Portugal - Ukraine

\begin{tabular}{|l|c|c|c|c|c|}
\hline \hline Products (HS-4) & $\begin{array}{c}2014 \\
\text { (€ Million) }\end{array}$ & $\begin{array}{c}2018 \\
\text { (€ Million) }\end{array}$ & $\begin{array}{c}\text { CAGR } 14-18 \\
(\%)\end{array}$ & $\begin{array}{c}\text { Rank } \\
2018\end{array}$ & Share \\
\hline $\begin{array}{l}4407 \text { - Wood sawn or } \\
\text { chipped lengthwise, } \\
\text { sliced or peeled, .. }\end{array}$ & 0,9 & 1,1 & $4,4 \%$ & 3 & $10,0 \%$ \\
\hline $\begin{array}{l}7019-\text { Glass fibres, } \\
\text { incl. glass wool, and ar- } \\
\text { ticles thereof .. }\end{array}$ & 0,1 & 0,8 & $55,2 \%$ & 4 & $7,4 \%$ \\
\hline $\begin{array}{l}\text { 0304 - Fish fillets and } \\
\text { other fish meat, } \\
\text { whether or not minced, } \\
\text { fresh, chilled or frozen }\end{array}$ & 0,0 & 0,7 & n.a. & 5 & $7,0 \%$ \\
\hline $\begin{array}{l}5402-\text { Synthetic fila- } \\
\text { ment yarn, incl. syn- } \\
\text { thetic monofilaments of } \\
<67 \text { decitex ... }\end{array}$ & 0,0 & 0,6 & $92,3 \%$ & 6 & $5,7 \%$ \\
\hline $\begin{array}{l}2703-\text { Peat, incl. peat } \\
\text { litter, whether or not } \\
\text { agglomerated }\end{array}$ & 0,3 & 0,6 & $16,6 \%$ & 7 & $5,4 \%$ \\
\hline $\begin{array}{l}3208-\text { Paints and var- } \\
\text { nishes, incl. enamels } \\
\text { and lacquers, based on } \\
\text { synthetic polymers ... }\end{array}$ & 0,0 & 0,3 & $67,4 \%$ & 8 & $2,6 \%$ \\
\hline $\begin{array}{l}4412-\text { Plywood, ve- } \\
\text { neered panel and simi- } \\
\text { lar laminated wood, cel- } \\
\text { lular ... }\end{array}$ & 0,1 & 0,2 & $14,5 \%$ & 9 & $2,0 \%$ \\
\hline \begin{tabular}{l}
$2834-$ Nitrites; nitrates \\
\hline
\end{tabular} & 0,0 & 0,2 & n.a. & 10 & $1,7 \%$ \\
\hline
\end{tabular}

Sources: COMTRADE, Feitoria Model

CAGR: Compound Annual Growth Rate; n.a.: not available.

Portugal - Poland. The commercial relations between Portugal and Poland increased significantly since Poland integrated into the European Union in 2004. In 2006 the bilateral trade between Portugal and Poland was around $€ 620.5$ million and in 2018 it was around $€ 1,779.9$ million, representing an increase of $186.9 \%$.

In 2018, Portugal exported 589 products to Poland (of 1,254 products total). Between 2014 and 2018, the exports from Portugal to Poland had growth $11.9 \%$ to $€ 828.3$ million (more than the exports to the World: $5.5 \%$ ). The 10 largest products in value represent $44.1 \%$ of total products exported from Portugal to Poland. Table 4 presents the Top 10 exported products in value. 
Table 4

Top 10 products in value exported: Portugal to Poland

\begin{tabular}{|c|c|c|c|c|c|}
\hline Products (HS-4) & $\begin{array}{c}2014 \\
(€ \text { Million) }\end{array}$ & $\begin{array}{c}2018 \\
\text { (€ Million) }\end{array}$ & $\begin{array}{c}\text { CAGR }_{14-18} \\
(\%)\end{array}$ & $\begin{array}{l}\text { Rank } \\
2018 \\
\end{array}$ & Share \\
\hline TOTAL - All products & 473,0 & 828,3 & $11,9 \%$ & & \\
\hline $\begin{array}{l}4703-\text { Chemical wood } \\
\text { pulp, soda or sulphate } \\
\text { (excluding dissolving } \\
\text { grades) }\end{array}$ & 36,1 & 83,4 & $18,2 \%$ & 1 & $10,1 \%$ \\
\hline $\begin{array}{l}8703 \text { - Motor cars and } \\
\text { other motor vehicles } \\
\text { principally ... }\end{array}$ & 0,0 & 65,1 & n.a. & 2 & $7,9 \%$ \\
\hline $\begin{array}{l}8708 \text { - Parts and ac- } \\
\text { cessories for tractors, } \\
\text { motor vehicles for the } \\
\text { transport of, ... }\end{array}$ & 32,2 & 54,8 & $11,2 \%$ & 3 & $6,6 \%$ \\
\hline $\begin{array}{l}8480 \text { - Moulding boxes } \\
\text { for metal foundry; } \\
\text { mould bases; moulding } \\
\text { patterns; moulds ... }\end{array}$ & 19,9 & 34,6 & $11,7 \%$ & 4 & $4,2 \%$ \\
\hline $\begin{array}{l}2204-\text { Wine of fresh } \\
\text { grapes, incl. fortified } \\
\text { wines; grape must ... }\end{array}$ & 14,6 & 25,1 & $11,4 \%$ & 5 & $3,0 \%$ \\
\hline $\begin{array}{l}8544 \text { - Insulated «incl. } \\
\text { enamelled or anodised» } \\
\text { wire, cable «incl. coax- } \\
\text { ial cable» ... }\end{array}$ & 16,8 & 24,1 & $7,5 \%$ & 6 & $2,9 \%$ \\
\hline $\begin{array}{l}4011 \text { - New pneumatic } \\
\text { tyres, of rubber }\end{array}$ & 17,3 & 21,9 & $4,8 \%$ & 7 & $2,6 \%$ \\
\hline $\begin{array}{l}6403 \text { - Footwear with } \\
\text { outer soles of rubber, } \\
\text { plastics, leather ... }\end{array}$ & 6,3 & 21,4 & $27,5 \%$ & 8 & $2,6 \%$ \\
\hline $\begin{array}{l}0805 \text { - Citrus fruit, fresh } \\
\text { or dried }\end{array}$ & 8,0 & 20,7 & $20,8 \%$ & 9 & $2,5 \%$ \\
\hline $\begin{array}{l}3004 \text { - Medicaments } \\
\text { consisting of mixed or } \\
\text { unmixed products for } \\
\text { therapeutic ... }\end{array}$ & 5,5 & 14,8 & $21,9 \%$ & 10 & $1,8 \%$ \\
\hline
\end{tabular}

Sources: COMTRADE, Feitoria Model

CAGR: Compound Annual Growth Rate; n.a.: not available. 
108 José Manuel M. Botelho, Iveta Mietule, Serhii Hushko, Volodymyr Kulishov, Irina Maksymova

Comparative advantages of international trade: the bilateral opportunities Portugal - Latvia, Portugal - Poland and Portugal - Ukraine

Poland - Portugal. In 2018, Poland exported 638 products to Portugal (of 1,254 products total). Between 2014 and 2018, the exports from Poland to Portugal had grown $12.1 \%$ to $€ 951.6$ million (more than the export growth to the World: $6.6 \%$ ). The 10 largest products in value represent $50.5 \%$ of total products exported from Poland to Portugal.

Table 5 presents the Top 10 exported products in value.

Table 5

Top 10 products in value exported: Poland to Portugal

\begin{tabular}{|c|c|c|c|c|c|}
\hline Products (HS-4) & $\begin{array}{c}2014 \\
(€ \text { Million) }\end{array}$ & $\begin{array}{c}2018 \\
(€ \text { Million) }\end{array}$ & $\begin{array}{c}\text { CAGR }_{14-18} \\
(\%)\end{array}$ & $\begin{array}{l}\text { Rank } \\
2018 \\
\end{array}$ & Share \\
\hline TOTAL - All products & 536,9 & 951,6 & $12,1 \%$ & & \\
\hline $\begin{array}{l}9401-\text { Seats, whether } \\
\text { or not convertible into } \\
\text { beds, and parts thereof, } \\
\text { n.e.s., ... }\end{array}$ & 64,5 & 121,5 & $13,5 \%$ & 1 & $12,8 \%$ \\
\hline $\begin{array}{l}8528 \text { - Monitors and } \\
\text { projectors, not incorpo- } \\
\text { rating television recep- } \\
\text { tion apparatus; ... }\end{array}$ & 46,2 & 82,7 & $12,3 \%$ & 2 & $8,7 \%$ \\
\hline $\begin{array}{l}8708 \text { - Parts and ac- } \\
\text { cessories for tractors, } \\
\text { motor vehicles for the } \\
\text { transport of ten, ... }\end{array}$ & 33,1 & 72,6 & $17,0 \%$ & 3 & $7,6 \%$ \\
\hline $\begin{array}{l}8703-\text { Motor cars and } \\
\text { other motor vehicles } \\
\text { principally for the trans- } \\
\text { port of persons, ... }\end{array}$ & 3,4 & 45,9 & $67,9 \%$ & 4 & $4,8 \%$ \\
\hline $\begin{array}{l}3815 \text { - Reaction initia- } \\
\text { tors, reaction accelera- } \\
\text { tors and catalytic prepa- } \\
\text { rations, n.e.s., ... }\end{array}$ & 0,0 & 36,6 & $326,4 \%$ & 5 & $3,8 \%$ \\
\hline $\begin{array}{l}0201 \text { - Meat of bovine } \\
\text { animals, fresh or chilled }\end{array}$ & 25,3 & 31,2 & $4,3 \%$ & 6 & $3,3 \%$ \\
\hline $\begin{array}{l}2402 \text { - Cigars, che- } \\
\text { roots, cigarillos and } \\
\text { cigarettes of tobacco or } \\
\text { of tobacco substitutes }\end{array}$ & 6,8 & 30,5 & $35,0 \%$ & 7 & $3,2 \%$ \\
\hline $\begin{array}{l}8471 \text { - Automatic data- } \\
\text { processing machines } \\
\text { and units thereof; ... }\end{array}$ & 11,0 & 22,3 & $15,3 \%$ & 8 & $2,3 \%$ \\
\hline
\end{tabular}




\begin{tabular}{|l|c|c|c|c|c|}
\hline \hline \multicolumn{1}{|c|}{ Products (HS-4) } & $\begin{array}{c}2014 \\
\text { (€ Million) }\end{array}$ & $\begin{array}{c}2018 \\
\text { (€ Million) }\end{array}$ & $\begin{array}{c}\text { CAGR } \\
(\%)\end{array}$ & $\begin{array}{c}\text { Rank } \\
2018\end{array}$ & Share \\
\hline $\begin{array}{l}8418-\text { Refrigerators, } \\
\text { freezers and other re- } \\
\text { frigerating or freezing } \\
\text { equipment, .. }\end{array}$ & 9,5 & 21,9 & $18,1 \%$ & 9 & $2,3 \%$ \\
\hline $\begin{array}{l}8450-\text { Household or } \\
\text { laundry-type washing } \\
\text { machines, incl. Ma- } \\
\text { chines ... }\end{array}$ & 12,2 & 15,9 & $5,4 \%$ & 10 & $1,7 \%$ \\
\hline
\end{tabular}

Sources: COMTRADE, Feitoria Model

CAGR: Compound Annual Growth Rate

Portugal - Ukraine. In 2006, the bilateral trade between Portugal and Ukraine was around €44.3 million and in 2018 it was around €288.1 million, representing an increase of $550.3 \%$. In 2018, Portugal exported 221 products to Ukraine (of 1,254 products total). Between 2014 and 2018, the exports from Portugal to Ukraine had growth $2.2 \%$ to $€ 24.9$ million (less than the exports to the World: $5.5 \%$ ). The 10 largest products in value represent $58.3 \%$ of total products exported from Portugal to Ukraine. Table 6 presents the Top 10 exported products in value.

Table 6

Top 10 products in value exported: Portugal to Ukraine

\begin{tabular}{|l|c|c|c|c|c|c|}
\hline \multicolumn{1}{|c|}{ Products (HS-4) } & $\begin{array}{c}2014 \\
\text { (€ Million) }\end{array}$ & $\begin{array}{c}2018 \\
\text { (€ Million) }\end{array}$ & $\begin{array}{c}\text { CAGR }_{14-18} \\
(\%)\end{array}$ & $\begin{array}{c}\text { Rank } \\
2018\end{array}$ & Share & $\begin{array}{c}\text { MFN } \\
\text { Applied } \\
\text { Tariff }\end{array}$ \\
\hline $\begin{array}{l}\text { TOTAL - All prod- } \\
\text { ucts }\end{array}$ & 22,4 & 24,9 & $2,2 \%$ & & & \\
\hline $\begin{array}{l}4504-\text { Agglomer- } \\
\text { ated cork, with or } \\
\text { without a binding } \\
\text { substance, .. }\end{array}$ & 3,8 & 3,5 & $-1,4 \%$ & 1 & $14,1 \%$ & $1,88 \%$ \\
\hline $\begin{array}{l}6403-\text { Footwear } \\
\text { with outer soles of } \\
\text { rubber, plastics, } \\
\text { leather ... }\end{array}$ & 1,6 & 2,3 & $7,0 \%$ & 2 & $9,0 \%$ & $6,67 \%$ \\
\hline
\end{tabular}


110 José Manuel M. Botelho, Iveta Mietule, Serhii Hushko, Volodymyr Kulishov, Irina Maksymova

Comparative advantages of international trade: the bilateral opportunities

Portugal - Latvia, Portugal - Poland and Portugal - Ukraine

\begin{tabular}{|c|c|c|c|c|c|c|}
\hline Products (HS-4) & $\begin{array}{c}2014 \\
(€ \text { Million) }\end{array}$ & $\begin{array}{c}2018 \\
(€ \text { Million })\end{array}$ & $\begin{array}{c}\text { CAGR }_{14-18} \\
(\%)\end{array}$ & $\begin{array}{l}\text { Rank } \\
2018\end{array}$ & Share & $\begin{array}{l}\text { MFN } \\
\text { Applied } \\
\text { Tariff }\end{array}$ \\
\hline $\begin{array}{l}7324 \text { - Sanitary } \\
\text { ware, and parts } \\
\text { thereof, of iron or } \\
\text { steel ... }\end{array}$ & 1,0 & 1,5 & $8,3 \%$ & 3 & $6,2 \%$ & $3,58 \%$ \\
\hline $\begin{array}{l}4503-\text { Articles of } \\
\text { natural cork ... }\end{array}$ & 1,2 & 1,4 & $3,6 \%$ & 4 & $5,6 \%$ & $10,00 \%$ \\
\hline $\begin{array}{l}0901-\text { Coffee, } \\
\text { whether or not } \\
\text { roasted or decaf- } \\
\text { feinated; coffee } \\
\text { husks and skins; }\end{array}$ & 1,3 & 1,4 & $1,9 \%$ & 5 & $5,5 \%$ & $4,00 \%$ \\
\hline $\begin{array}{l}2204-\text { Wine of } \\
\text { fresh grapes, incl. } \\
\text { fortified wines; } \\
\text { grape must ... }\end{array}$ & 0,5 & 1,2 & $16,4 \%$ & 6 & $4,7 \%$ & $6,25 \%$ \\
\hline $\begin{array}{l}8536 \text { - Electrical } \\
\text { apparatus for } \\
\text { switching or pro- } \\
\text { tecting electrical } \\
\text { circuits, ... }\end{array}$ & 0,8 & 1,0 & $4,4 \%$ & 7 & $4,0 \%$ & $5,00 \%$ \\
\hline $\begin{array}{l}8419 \text { - Machinery, } \\
\text { plant or laboratory } \\
\text { equipment ... }\end{array}$ & 0,7 & 1,0 & $8,1 \%$ & 8 & $3,9 \%$ & $0,89 \%$ \\
\hline $\begin{array}{l}0402 \text { - Milk and } \\
\text { cream, concen- } \\
\text { trated or contain- } \\
\text { ing added sugar }\end{array}$ & 0,7 & 0,7 & $-2,3 \%$ & 9 & $2,6 \%$ & $10,00 \%$ \\
\hline $\begin{array}{l}8428 \text { - Lifting, } \\
\text { handling, loading } \\
\text { or unloading ma- } \\
\text { chinery, e.g. lifts, } \\
\text { escalators, ... }\end{array}$ & 0,0 & 0,7 & $67,7 \%$ & 10 & $2,6 \%$ & $10,00 \%$ \\
\hline
\end{tabular}

Sources: COMTRADE, Feitoria Model

CAGR: Compound Annual Growth Rate 
Ukraine - Portugal. In 2018, Ukraine exported 128 products to Portugal (of 1,254 products total). Between 2014 and 2018, the exports from Ukraine to Portugal had grown $2.1 \%$ to $€ 261.2$ million (more than the export growth to the World: $-0.2 \%$ ). The 10 largest products in value represent $96.1 \%$ of total products exported from Ukraine to Portugal. Table 7 presents the Top 10 exported products in value.

Table 7

Top 10 products in value exported: Ukraine to Portugal

\begin{tabular}{|c|c|c|c|c|c|c|}
\hline Products (HS-4) & $\begin{array}{c}2014 \\
(€ \text { Million) }\end{array}$ & $\begin{array}{c}2018 \\
(€ \text { Million) }\end{array}$ & $\begin{array}{l}\text { CAGR }_{14-18} \\
(\%)\end{array}$ & $\begin{array}{l}\text { Rank } \\
2018\end{array}$ & Share & $\begin{array}{c}\text { MFN } \\
\text { Applied } \\
\text { Tariff }\end{array}$ \\
\hline $\begin{array}{l}\text { TOTAL - All prod- } \\
\text { ucts }\end{array}$ & 235,5 & 261,2 & $2,1 \%$ & & & - \\
\hline 1005 - Maize or corn & 107,4 & 150,3 & $7,0 \%$ & 1 & $57,6 \%$ & $0,0 \%$ \\
\hline $\begin{array}{l}1205 \text { - Rape or } \\
\text { colza seeds, } \\
\text { whether or not } \\
\text { broken }\end{array}$ & 59,2 & 31,6 & $-11,8 \%$ & 2 & $12,1 \%$ & $0,0 \%$ \\
\hline $\begin{array}{l}7209-\text { Flat-rolled } \\
\text { products of iron or } \\
\text { non-alloy steel, } \\
\text { cold-rolled «cold- } \\
\text { reduced», ... }\end{array}$ & 4,6 & 22,5 & $37,3 \%$ & 3 & $8,6 \%$ & $0,0 \%$ \\
\hline $\begin{array}{l}7208 \text { - Flat-rolled } \\
\text { products of iron or } \\
\text { non-alloy steel, hot- } \\
\text { rolled, not clad, ... }\end{array}$ & 25,7 & 19,5 & $-5,4 \%$ & 4 & $7,4 \%$ & $0,0 \%$ \\
\hline $\begin{array}{l}7202 \text { - Ferro- } \\
\text { alloys }\end{array}$ & 4,2 & 6,0 & $7,2 \%$ & 5 & $2,3 \%$ & $\begin{array}{l}60.5 \\
\text { EUR } \\
\text { TNE }\end{array}$ \\
\hline $\begin{array}{l}1001-\text { Wheat and } \\
\text { meslin }\end{array}$ & 0,0 & 5,8 & n.a. & 6 & $2,2 \%$ & $0,0 \%$ \\
\hline $\begin{array}{l}2306 \text { - Oilcake } \\
\text { and other solid } \\
\text { residues, whether } \\
\text { or not ground ... }\end{array}$ & 0,0 & 5,5 & n.a. & 7 & $2,1 \%$ & $\begin{array}{l}0.0 \% \text { to } \\
2.8 \%\end{array}$ \\
\hline $\begin{array}{l}1512 \text { - Sunflower- } \\
\text { seed, safflower or } \\
\text { cotton-seed oil and } \\
\text { fractions thereof, ... }\end{array}$ & 8,9 & 4,0 & $-14,8 \%$ & 8 & $1,5 \%$ & $0,0 \%$ \\
\hline
\end{tabular}


Comparative advantages of international trade: the bilateral opportunities Portugal - Latvia, Portugal - Poland and Portugal - Ukraine

\begin{tabular}{|l|c|c|c|c|c|c|}
\hline \hline Products (HS-4) & $\begin{array}{c}2014 \\
\text { (€ Million) }\end{array}$ & $\begin{array}{c}2018 \\
\text { (€ Million) }\end{array}$ & $\begin{array}{c}\text { CAGR }_{14-18} \\
(\%)\end{array}$ & $\begin{array}{c}\text { Rank } \\
2018\end{array}$ & Share & $\begin{array}{c}\text { MFN } \\
\text { Applied } \\
\text { Tariff }\end{array}$ \\
\hline $\begin{array}{l}7210-\text { Flat-rolled } \\
\text { products of iron or } \\
\text { non-alloy steel, of a } \\
\text { width >= 600 mm, ... }\end{array}$ & 0,0 & 3,7 & n.a. & 9 & $1,4 \%$ & $0,0 \%$ \\
\hline $\begin{array}{l}2711-\text { Petroleum } \\
\text { gas and other } \\
\text { gaseous hydro- } \\
\text { carbons }\end{array}$ & 0,0 & 2,1 & n.a. & 10 & $0,8 \%$ & $0,0 \%$ \\
\hline
\end{tabular}

Sources: COMTRADE, Feitoria Model

CAGR: Compound Annual Growth Rate; n.a.: not available.

\section{Modelling Results}

The Feitoria Model results for bilateral export opportunities between Portugal and Latvia, Poland and Ukraine are as follows.

Feitoria Model results «Portugal to Latvia». According to the results of Feitoria Model, there are 79 export opportunities from Portugal to Latvia. Table 8 presents the Top 10 export opportunities from Portugal to Latvia, sorted by value of Latvia imports from the World (largest to smallest) and complemented with the imports dynamism (the average growth rate in medium term, 2014-2018, and short term, 2017-2018).

\section{Table 8}

\section{Top 10 Export Opportunities from Portugal to Latvia}

\begin{tabular}{|l|c|c|c|c|c|c|}
\hline \multicolumn{1}{|c|}{ Products (HS-4) } & $\begin{array}{c}2014 \\
(€ \text { Million) }\end{array}$ & $\begin{array}{c}2018 \\
\text { (€ Million) }\end{array}$ & $\begin{array}{c}\text { CAGR } \\
(\%)\end{array}$ & $\begin{array}{c}\text { CAGR } 17-18 \\
(\%)\end{array}$ & $\begin{array}{c}\text { Rank } \\
2018\end{array}$ & $\begin{array}{c}\text { Share } \\
(\%)\end{array}$ \\
\hline $\begin{array}{l}\text { TOTAL - All prod- } \\
\text { ucts }\end{array}$ & 12885,4 & 15761,0 & $4,1 \%$ & $5,3 \%$ & - & - \\
\hline $\begin{array}{l}2208-\text { Undena- } \\
\text { tured ethyl alcohol } \\
\text { of an alcoholic } \\
\text { strength of < } 80 \% ; \\
\text { spirits, liqueurs, } \ldots\end{array}$ & 136,8 & 338,6 & $19,9 \%$ & $5,1 \%$ & 9 & $2,1 \%$ \\
\hline
\end{tabular}


English Edition. Vol. 20. № 1 (76). January-March 2021.

ISSN 2519-4070

\begin{tabular}{|c|c|c|c|c|c|c|}
\hline Products (HS-4) & $\begin{array}{c}2014 \\
\text { (€ Million) }\end{array}$ & $\begin{array}{c}2018 \\
\text { (€ Million) }\end{array}$ & $\begin{array}{c}\mathrm{CAGR}_{14-18} \\
(\%)\end{array}$ & $\begin{array}{c}\mathrm{CAGR}_{17-18} \\
(\%)\end{array}$ & $\begin{array}{l}\text { Rank } \\
2018\end{array}$ & $\begin{array}{c}\text { Share } \\
(\%)\end{array}$ \\
\hline $\begin{array}{l}7208 \text { - Flat-rolled } \\
\text { products of iron or } \\
\text { non-alloy steel, of a } \\
\text { width }>=600 \mathrm{~mm} \text {, } \\
\text { hot-rolled, ... }\end{array}$ & 125,9 & 202,7 & $10,0 \%$ & $19,4 \%$ & 13 & $1,3 \%$ \\
\hline $\begin{array}{l}4407 \text { - Wood sawn } \\
\text { or chipped length- } \\
\text { wise, sliced or } \\
\text { peeled, whether or } \\
\text { not planed, ... }\end{array}$ & 80,0 & 190,0 & $18,9 \%$ & $15,4 \%$ & 14 & $1,2 \%$ \\
\hline $\begin{array}{l}7306 \text { - Tubes, } \\
\text { pipes and hollow } \\
\text { profiles «e.g., open } \\
\text { seam or welded, } \\
\text { riveted, ... }\end{array}$ & 45,7 & 65,6 & $7,5 \%$ & $14,4 \%$ & 37 & $0,4 \%$ \\
\hline $\begin{array}{l}0207 \text { - Meat and } \\
\text { edible offal of fowls } \\
\text { of the species Gal- } \\
\text { lus domesticus, } \\
\text { ducks, geese, ... }\end{array}$ & 35,7 & 52,3 & $7,9 \%$ & $8,9 \%$ & 54 & $0,3 \%$ \\
\hline $\begin{array}{l}2203 \text { - Beer made } \\
\text { from malt }\end{array}$ & 27,2 & 48,6 & $12,3 \%$ & $7,9 \%$ & 59 & $0,3 \%$ \\
\hline $\begin{array}{l}8526 \text { - Radar appa- } \\
\text { ratus, radio naviga- } \\
\text { tional aid apparatus } \\
\text { and radio remote } \\
\text { control ... }\end{array}$ & 15,3 & 34,2 & $17,4 \%$ & $136,9 \%$ & 89 & $0,2 \%$ \\
\hline $\begin{array}{l}4819 \text { - Cartons, } \\
\text { boxes, cases, bags } \\
\text { and other packing } \\
\text { containers, of pa- } \\
\text { per, paperboard, ... }\end{array}$ & 23,8 & 32,9 & $6,7 \%$ & $5,3 \%$ & 93 & $0,2 \%$ \\
\hline $\begin{array}{l}3208 \text { - Paints and } \\
\text { varnishes, incl. ena- } \\
\text { mels and lacquers, } \\
\text { based on synthetic } \\
\text { polymers ... }\end{array}$ & 20,4 & 28,4 & $6,9 \%$ & $8,7 \%$ & 108 & $0,2 \%$ \\
\hline $\begin{array}{l}6810-\text { Articles of } \\
\text { cement, concrete } \\
\text { or artificial stone, } \\
\text { whether or not rein- } \\
\text { forced }\end{array}$ & 15,6 & 28,2 & $12,6 \%$ & $12,4 \%$ & 110 & $0,2 \%$ \\
\hline
\end{tabular}

Source: Feitoria Model developed by authors. 
114 José Manuel M. Botelho, Iveta Mietule, Serhii Hushko, Volodymyr Kulishov, Irina Maksymova

Comparative advantages of international trade: the bilateral opportunities

Portugal - Latvia, Portugal - Poland and Portugal - Ukraine

Feitoria Model results «Latvia to Portugal». According to the results of Feitoria Model, there are 122 export opportunities from Latvia to Portugal. Table 9 presents the Top 10 export opportunities from Poland to Portugal, sorted by value of Portugal imports from the World (largest to smallest) and complemented with the imports dynamism (the average growth rate in medium term, 20142018, and short term, 2017-2018).

Table 9

Top 10 Export Opportunities from Latvia to Portugal

\begin{tabular}{|c|c|c|c|c|c|c|}
\hline Products (HS-4) & $\begin{array}{c}2014 \\
(€ \text { Million) }\end{array}$ & $\begin{array}{c}2018 \\
(€ \text { Million) }\end{array}$ & $\begin{array}{l}\text { CAGR }_{14-18} \\
(\%)\end{array}$ & $\begin{array}{l}\text { CAGR }_{17-18} \\
(\%)\end{array}$ & $\begin{array}{l}\text { Rank } \\
2018\end{array}$ & $\begin{array}{c}\text { Share } \\
(\%)\end{array}$ \\
\hline $\begin{array}{l}\text { TOTAL - All prod- } \\
\text { ucts }\end{array}$ & 58977,7 & 80974,8 & $6,5 \%$ & $7,8 \%$ & - & - \\
\hline $\begin{array}{l}8708-\text { Parts and } \\
\text { accessories for trac- } \\
\text { tors, motor vehicles } \\
\text { for the transport of } \\
10 \text { or more, ... }\end{array}$ & 2078,3 & 3034,6 & $7,9 \%$ & $11,4 \%$ & 3 & $3,7 \%$ \\
\hline $\begin{array}{l}7208 \text { - Flat-rolled } \\
\text { products of iron or } \\
\text { non-alloy steel, of a } \\
\text { width }>=600 \mathrm{~mm} \text {, } \\
\text { hot-rolled, ... }\end{array}$ & 401,9 & 640,8 & $9,8 \%$ & $13,8 \%$ & 11 & $0,8 \%$ \\
\hline $\begin{array}{l}0201 \text { - Meat of bo- } \\
\text { vine animals, fresh } \\
\text { or chilled }\end{array}$ & 356,1 & 508,1 & $7,4 \%$ & $10,0 \%$ & 16 & $0,6 \%$ \\
\hline $\begin{array}{l}3907 \text { - Polyacetals, } \\
\text { other polyethers } \\
\text { and epoxide resins, } \\
\text { in primary forms; } \\
\text { polycarbonates, ... }\end{array}$ & 350,2 & 497,2 & $7,3 \%$ & $9,2 \%$ & 18 & $0,6 \%$ \\
\hline 1005 - Maize or corn & 325,0 & 485,0 & $8,3 \%$ & $15,3 \%$ & 21 & $0,6 \%$ \\
\hline $\begin{array}{l}0305 \text { - Fish, fit for } \\
\text { human consumption, } \\
\text { dried, salted or in bri- } \\
\text { ne; smoked fish, ... }\end{array}$ & 276,3 & 390,3 & $7,2 \%$ & $5,6 \%$ & 32 & $0,5 \%$ \\
\hline $\begin{array}{l}8528 \text { - Monitors } \\
\text { and projectors, not } \\
\text { incorporating tele- } \\
\text { vision reception } \\
\text { apparatus; ... }\end{array}$ & 272,1 & 377,0 & $6,7 \%$ & $13,0 \%$ & 34 & $0,5 \%$ \\
\hline
\end{tabular}




\begin{tabular}{|l|c|c|c|c|c|c|}
\hline \hline Products (HS-4) & $\begin{array}{c}2014 \\
\text { (€ Million) }\end{array}$ & $\begin{array}{c}2018 \\
\text { (€ Million) }\end{array}$ & $\begin{array}{c}\text { CAGR }_{14-18} \\
(\%)\end{array}$ & $\begin{array}{c}\text { CAGR }_{17-18} \\
(\%)\end{array}$ & $\begin{array}{c}\text { Rank } \\
2018\end{array}$ & $\begin{array}{c}\text { Share } \\
(\%)\end{array}$ \\
\hline $\begin{array}{l}1905 \text { - Bread, pas- } \\
\text { try, cakes, biscuits } \\
\text { and other bakers' } \\
\text { wares, .. }\end{array}$ & 290,0 & 376,7 & $5,4 \%$ & $6,5 \%$ & 35 & $0,5 \%$ \\
\hline $\begin{array}{l}8411-\text { Turbojets, } \\
\text { turbopropellers and } \\
\text { other gas turbines }\end{array}$ & 132,6 & 375,5 & $23,2 \%$ & $28,5 \%$ & 36 & $0,5 \%$ \\
\hline $\begin{array}{l}2309-\text { Prepara- } \\
\text { tions of a kind used } \\
\text { in animal feeding }\end{array}$ & 224,6 & 302,2 & $6,1 \%$ & $6,5 \%$ & 50 & $0,4 \%$ \\
\hline
\end{tabular}

Source: Feitoria Model developed by authors.

Feitoria Model results «Portugal to Poland». According to the results of Feitoria Model, there are 162 export opportunities from Portugal to Poland. Table 10 presents the Top 10 export opportunities from Portugal to Poland, sorted by value of Poland imports from the World (largest to smallest) and complemented with the imports dynamism (the average growth rate in medium term, 20142018, and short term, $2017-2018$ ).

Table 10

Top 10 Export Opportunities from Portugal to Poland

\begin{tabular}{|l|c|c|c|c|c|c|}
\hline \multicolumn{1}{|c|}{ Products (HS-4) } & $\begin{array}{c}2014 \\
\text { (€ Million) }\end{array}$ & $\begin{array}{c}2018 \\
(€ \text { Million) }\end{array}$ & $\begin{array}{c}\text { CAGR }_{14-18} \\
(\%)\end{array}$ & $\begin{array}{c}\text { CAGR }_{17-18} \\
(\%)\end{array}$ & $\begin{array}{c}\text { Rank } \\
2018\end{array}$ & $\begin{array}{c}\text { Share } \\
(\%)\end{array}$ \\
\hline $\begin{array}{l}\text { TOTAL - All prod- } \\
\text { ucts }\end{array}$ & $\begin{array}{c}163 \\
015,1\end{array}$ & $\begin{array}{c}226 \\
676,7\end{array}$ & $6,8 \%$ & $8,4 \%$ & - & - \\
\hline $\begin{array}{l}8704 \text { - Motor vehi- } \\
\text { cles for the trans- } \\
\text { port of goods, incl. } \\
\text { chassis with engine } \\
\text { and cab }\end{array}$ & 1057,5 & 1772,0 & $10,9 \%$ & $12,0 \%$ & 14 & $0,8 \%$ \\
\hline $\begin{array}{l}7208-\text { Flat-rolled } \\
\text { products of iron or } \\
\text { non-alloy steel, of a } \\
\text { width >=600 mm, } \\
\text { hot-rolled, ... }\end{array}$ & 1067,5 & 1669,9 & $9,4 \%$ & $13,4 \%$ & 17 & $0,7 \%$ \\
\hline
\end{tabular}


116 José Manuel M. Botelho, Iveta Mietule, Serhii Hushko, Volodymyr Kulishov, Irina Maksymova

Comparative advantages of international trade: the bilateral opportunities

Portugal - Latvia, Portugal - Poland and Portugal - Ukraine

\begin{tabular}{|c|c|c|c|c|c|c|}
\hline Products (HS-4) & $\begin{array}{c}2014 \\
(€ \text { Million) }\end{array}$ & $\begin{array}{c}2018 \\
\text { (€ Million) }\end{array}$ & $\begin{array}{c}\text { CAGR }_{14-18} \\
(\%)\end{array}$ & $\begin{array}{c}\text { CAGR }_{17-18} \\
(\%)\end{array}$ & \begin{tabular}{|l|} 
Rank \\
2018 \\
\end{tabular} & $\begin{array}{c}\text { Share } \\
(\%)\end{array}$ \\
\hline $\begin{array}{l}3901-\text { Polymers of } \\
\text { ethylene, in primary } \\
\text { forms }\end{array}$ & 1040,6 & 1437,3 & $6,7 \%$ & $5,8 \%$ & 24 & $0,6 \%$ \\
\hline $\begin{array}{l}9401-\text { Seats, } \\
\text { whether or not con- } \\
\text { vertible into beds, } \\
\text { and parts thereof, } \\
\text { n.e.s., ... }\end{array}$ & 745,3 & 1390,1 & $13,3 \%$ & $7,1 \%$ & 28 & $0,6 \%$ \\
\hline $\begin{array}{l}8481 \text { - Taps, } \\
\text { cocks, valves and } \\
\text { similar appliances } \\
\text { for pipes, boiler } \\
\text { shells, tanks, ... }\end{array}$ & 847,9 & 1217,9 & $7,5 \%$ & $7,6 \%$ & 34 & $0,5 \%$ \\
\hline $\begin{array}{l}7326-\text { Articles of } \\
\text { iron or steel, n.e.s. } \\
\text { (excluding cast ar- } \\
\text { ticles) }\end{array}$ & 833,6 & 1190,2 & $7,4 \%$ & $7,7 \%$ & 36 & $0,5 \%$ \\
\hline $\begin{array}{l}6204 \text { - Women's or } \\
\text { girls' suits, ensem- } \\
\text { bles, jackets, blaz- } \\
\text { ers, dresses, skirts, } \\
\text { divided skirts, ... }\end{array}$ & 584,5 & 1133,6 & $14,2 \%$ & $22,8 \%$ & 40 & $0,5 \%$ \\
\hline $\begin{array}{l}3923 \text { - Articles for } \\
\text { the conveyance or } \\
\text { packaging of } \\
\text { goods, of plastics; } \\
\text { stoppers, lids, ... }\end{array}$ & 767,0 & 1087,3 & $7,2 \%$ & $8,4 \%$ & 41 & $0,5 \%$ \\
\hline $\begin{array}{l}8507 \text { - Electric ac- } \\
\text { cumulators, incl. } \\
\text { separators therefor, } \\
\text { whether or not } \\
\text { square or rectangu- } \\
\text { lar; }\end{array}$ & 403,0 & 1077,7 & $21,7 \%$ & $34,2 \%$ & 43 & $0,5 \%$ \\
\hline $\begin{array}{l}0302-\text { Fish, fresh } \\
\text { or chilled (exclud- } \\
\text { ing fish fillets and } \\
\text { other fish meat of } \\
\text { heading 0304) }\end{array}$ & 692,2 & 1048,6 & $8,7 \%$ & $5,4 \%$ & 45 & $0,5 \%$ \\
\hline
\end{tabular}

Source: Feitoria Model developed by authors 
Feitoria Model results «Poland to Portugal». According to the results of Feitoria Model, there are 145 export opportunities from Poland to Portugal. Table 11 presents the Top 10 export opportunities from Poland to Portugal, sorted by value of Portugal imports from the World (largest to smallest) and complemented with the imports dynamism (the average growth rate in medium term, 20142018, and short term, 2017-2018).

\section{Table 11}

Top 10 Export Opportunities from Poland to Portugal

\begin{tabular}{|l|c|c|c|c|c|c|}
\hline \multicolumn{1}{|c|}{ Products (HS-4) } & $\begin{array}{c}2014 \\
\text { (€ Million) }\end{array}$ & $\begin{array}{c}2018 \\
(€ \text { Million) }\end{array}$ & $\begin{array}{c}\text { CAGR }_{14-18} \\
(\%)\end{array}$ & $\begin{array}{c}\text { CAGR } \\
(\%)\end{array}$ & $\begin{array}{c}\text { Rank } \\
2018\end{array}$ & $\begin{array}{c}\text { Share } \\
(\%)\end{array}$ \\
\hline $\begin{array}{l}\text { TOTAL - All prod- } \\
\text { ucts }\end{array}$ & 58977,7 & 80974,8 & $6,5 \%$ & $7,8 \%$ & - & - \\
\hline $\begin{array}{l}8704-\text { Motor vehi- } \\
\text { cles for the trans- } \\
\text { port of goods, incl. } \\
\text { chassis with engine } \\
\text { and cab }\end{array}$ & 276,5 & 596,9 & $16,6 \%$ & $8,3 \%$ & 12 & $0,7 \%$ \\
\hline $\begin{array}{l}3907 \text { - Polyacet- } \\
\text { als, other polyeth- } \\
\text { ers and epoxide } \\
\text { resins, in primary } \\
\text { forms; } \ldots\end{array}$ & 350,2 & 497,2 & $7,3 \%$ & $9,2 \%$ & 18 & $0,6 \%$ \\
\hline $\begin{array}{l}7210-\text { Flat-rolled } \\
\text { products of iron or } \\
\text { non-alloy steel, of a } \\
\text { width >= 600 mm, } \\
\ldots\end{array}$ & 293,5 & 486,8 & $10,7 \%$ & $7,4 \%$ & 20 & $0,6 \%$ \\
\hline $\begin{array}{l}\text { 1005 - Maize or } \\
\text { corn }\end{array}$ & 325,0 & 485,0 & $8,3 \%$ & $15,3 \%$ & 21 & $0,6 \%$ \\
\hline $\begin{array}{l}8544-\text { Insulated } \\
\text { «incl. enamelled or } \\
\text { anodised» wire, } \\
\text { cable «incl. coaxial } \\
\text { cable» ... }\end{array}$ & 324,9 & 478,9 & $8,1 \%$ & $13,0 \%$ & 23 & $0,6 \%$ \\
\hline $\begin{array}{l}\text { 0305 - Fish, fit for } \\
\text { human consump- } \\
\text { tion, dried, salted } \\
\text { or in brine; smoked } \\
\text { fish, ... }\end{array}$ & 276,3 & 390,3 & $7,2 \%$ & $5,6 \%$ & 32 & $0,5 \%$ \\
\hline
\end{tabular}


118 José Manuel M. Botelho, Iveta Mietule, Serhii Hushko, Volodymyr Kulishov, Irina Maksymova

Comparative advantages of international trade: the bilateral opportunities

Portugal - Latvia, Portugal - Poland and Portugal - Ukraine

\begin{tabular}{|l|c|c|c|c|c|c|}
\hline \hline Products (HS-4) & $\begin{array}{c}2014 \\
\text { (€ Million) }\end{array}$ & $\begin{array}{c}2018 \\
\text { (€ Million) }\end{array}$ & $\begin{array}{c}\text { CAGR } 14-18 \\
(\%)\end{array}$ & $\begin{array}{c}\text { CAGR }_{17-18} \\
(\%)\end{array}$ & $\begin{array}{c}\text { Rank } \\
2018\end{array}$ & $\begin{array}{c}\text { Share } \\
(\%)\end{array}$ \\
\hline $\begin{array}{l}8408 \text { - Compres- } \\
\text { sion-ignition inter- } \\
\text { nal combustion pis- } \\
\text { ton engine «diesel» }\end{array}$ & 217,6 & 352,3 & $10,1 \%$ & $10,3 \%$ & 42 & $0,4 \%$ \\
\hline $\begin{array}{l}6204-\text { Women's or } \\
\text { girls' suits, ensem- } \\
\text { bles, jackets, blaz- } \\
\text { ers, dresses, skirts, } \\
\text { divided skirts }\end{array}$ & 252,5 & 343,2 & $6,3 \%$ & $7,6 \%$ & 44 & $0,4 \%$ \\
\hline $\begin{array}{l}6110-\text { Jerseys, } \\
\text { pullovers, cardi- } \\
\text { gans, waistcoats } \\
\text { and similar articles, } \\
\text { knitted or cro- } \\
\text { cheted ... }\end{array}$ & 218,8 & 282,5 & $5,2 \%$ & $8,7 \%$ & 54 & $0,3 \%$ \\
\hline $\begin{array}{l}7326-\text { Articles of } \\
\text { iron or steel, n.e.s. } \\
\text { (excluding cast ar- } \\
\text { ticles) }\end{array}$ & 174,8 & 259,6 & $8,2 \%$ & $16,4 \%$ & 62 & $0,3 \%$ \\
\hline
\end{tabular}

Source: Feitoria Model developed by authors

Feitoria Model results «Portugal to Ukraine». According to the results of Feitoria Model, there are 70 export opportunities from Portugal to Ukraine. Table 12 presents the Top 10 export opportunities from Portugal to Ukraine, sorted by value of Ukraine imports from the World (largest to smallest) and complemented with the imports dynamism (the average growth rate in medium term, 20142018, and short term, 2017-2018).

Table 12

Top 10 Export Opportunities from Portugal to Ukraine

\begin{tabular}{|c|c|c|c|c|c|c|c|}
\hline $\begin{array}{c}\text { Products } \\
\text { (HS-4) }\end{array}$ & $\begin{array}{c}2014 \\
\text { (€ Million) }\end{array}$ & $\begin{array}{c}2018 \\
\text { (€ Million) }\end{array}$ & $\begin{array}{c}\text { CAGR }_{14-18} \\
(\%)\end{array}$ & $\begin{array}{c}\text { CAGR }_{17-18} \\
(\%)\end{array}$ & $\begin{array}{c}\text { Rank } \\
2018\end{array}$ & $\begin{array}{c}\text { Share } \\
(\%)\end{array}$ & $\begin{array}{c}\text { MFN } \\
\text { Applied } \\
\text { Tariff }\end{array}$ \\
\hline $\begin{array}{l}\text { TOTAL-All } \\
\text { products }\end{array}$ & 40911,4 & 48423,6 & $3,4 \%$ & $5,2 \%$ & - & - & - \\
\hline
\end{tabular}




\begin{tabular}{|l|c|c|c|c|c|c|c|}
\hline \hline $\begin{array}{c}\text { Products } \\
\text { (HS-4) }\end{array}$ & $\begin{array}{c}2014 \\
\text { (€ Million) }\end{array}$ & $\begin{array}{c}2018 \\
\text { (€ Million) }\end{array}$ & $\begin{array}{c}\text { CAGR }_{14-18} \\
(\%)\end{array}$ & $\begin{array}{c}\text { CAGR }_{17-18} \\
(\%)\end{array}$ & $\begin{array}{c}\text { Rank } \\
2018\end{array}$ & $\begin{array}{c}\text { Share } \\
(\%)\end{array}$ & $\begin{array}{c}\text { MFN } \\
\text { Applied } \\
\text { Tariff }\end{array}$ \\
\hline $\begin{array}{l}2713-\text { Petro- } \\
\text { leum coke, } \\
\text { petroleum bi- } \\
\text { tumen ... }\end{array}$ & 42.8 & 243.9 & $41.6 \%$ & $22.7 \%$ & 29 & $0.5 \%$ & $3.0 \%$ \\
\hline $\begin{array}{l}8502-\text { Elec- } \\
\text { tric generating } \\
\text { sets and ro- } \\
\text { tary convert- } \\
\text { ers }\end{array}$ & 95.2 & 176.1 & $13.1 \%$ & $39.2 \%$ & 47 & $0.4 \%$ & $2.1 \%$ \\
\hline $\begin{array}{l}5407-\text { Woven } \\
\text { fabrics of syn- } \\
\text { thetic filament } \\
\text { yarn ... }\end{array}$ & 90.1 & 157.3 & $11.8 \%$ & $13.4 \%$ & 54 & $0.3 \%$ & $4.6 \%$ \\
\hline $\begin{array}{l}7214-\text { Bars } \\
\text { and rods, of } \\
\text { iron or non- } \\
\text { alloy steel, not } \\
\text { further worked } \\
\text { than forged, } \\
\text { hot-rolled .. }\end{array}$ & 46.8 & 144.6 & $25.3 \%$ & $13.4 \%$ & 62 & $0.3 \%$ & $0.0 \%$ \\
\hline $\begin{array}{l}8302-\text { Base } \\
\text { metal mount- } \\
\text { ings, fittings } \\
\text { and similar ar- } \\
\text { ticles suitable } \\
\text { furniture, } \\
\text { doors, ... }\end{array}$ & 101.9 & 132.8 & $5.4 \%$ & $5.7 \%$ & 72 & $0.3 \%$ & $6.0 \%$ \\
\hline $\begin{array}{l}4411-\text { Fibre- } \\
\text { board of wood } \\
\text { or other ligne- } \\
\text { ous materials } \\
\ldots\end{array}$ & 79.6 & 102.1 & $5.1 \%$ & $9.9 \%$ & 96 & $0.2 \%$ & $0.0 \%$ \\
\hline $\begin{array}{l}3909-\text { Amino- } \\
\text { resins, pheno- } \\
\text { lic resins and } \\
\text { polyure- } \\
\text { thanes, in pri- } \\
\text { mary forms }\end{array}$ & 76.9 & 99.8 & $5.3 \%$ & $7.5 \%$ & 98 & $0.2 \%$ & $3.7 \%$ \\
\hline $\begin{array}{l}0302-\text { Fish, } \\
\text { fresh or chilled }\end{array}$ & 69.6 & 90.9 & $5.5 \%$ & $8.8 \%$ & 113 & $0.2 \%$ & $0.6 \%$ \\
\hline
\end{tabular}


Portugal - Latvia, Portugal - Poland and Portugal - Ukraine

\begin{tabular}{|l|c|c|c|c|c|c|c|}
\hline \hline $\begin{array}{c}\text { Products } \\
\text { (HS-4) }\end{array}$ & $\begin{array}{c}2014 \\
\text { (€ Million) }\end{array}$ & $\begin{array}{c}2018 \\
\text { (€ Million) }\end{array}$ & $\begin{array}{c}\text { CAGR }_{14-18} \\
(\%)\end{array}$ & $\begin{array}{c}\text { CAGR }_{17-18} \\
(\%)\end{array}$ & $\begin{array}{c}\text { Rank } \\
2018\end{array}$ & $\begin{array}{c}\text { Share } \\
(\%)\end{array}$ & $\begin{array}{c}\text { MFN } \\
\text { Applied } \\
\text { Tariff }\end{array}$ \\
\hline $\begin{array}{l}2403-\text { Manu- } \\
\text { factured to- } \\
\text { bacco and } \\
\text { manufactured } \\
\text { tobacco sub- } \\
\text { stitutes ... }\end{array}$ & 67.7 & 90.4 & $6.0 \%$ & $17.6 \%$ & 114 & $0.2 \%$ & $20.0 \%$ \\
\hline $\begin{array}{l}8438-\text { Ma- } \\
\text { chinery for the } \\
\text { industrial } \\
\text { preparation ... }\end{array}$ & 45.3 & 74.4 & $10.4 \%$ & $14.5 \%$ & 124 & $0.2 \%$ & $3.9 \%$ \\
\hline
\end{tabular}

Source: Feitoria Model developed by authors.

Feitoria Model results «Ukraine to Portugal». According to the results of Feitoria Model, there are 95 export opportunities from Ukraine to Portugal. Table 13 presents the Top 10 export opportunities from Ukraine to Portugal, sorted by value of Portugal imports from the World (largest to smallest) and complemented with the imports dynamism (the average growth rate in medium term, 20142018, and short term, 2017-2018).

Table 13

Top 10 Export Opportunities from Ukraine to Portugal

\begin{tabular}{|l|l|l|l|l|l|l|l|}
\hline $\begin{array}{c}\text { Products } \\
\text { (HS-4) }\end{array}$ & \multicolumn{1}{|c|}{$\begin{array}{c}2014 \\
\text { (€ Million) }\end{array}$} & $\begin{array}{c}2018 \\
\text { (€ Million) }\end{array}$ & $\begin{array}{c}\text { CAGR }_{14-18} \\
(\%)\end{array}$ & $\begin{array}{c}\text { CAGR }_{17-18} \\
(\%)\end{array}$ & $\begin{array}{c}\text { Rank } \\
2018\end{array}$ & $\begin{array}{c}\text { Share } \\
(\%)\end{array}$ & $\begin{array}{c}\text { MFN } \\
\text { Applied } \\
\text { Tariff }\end{array}$ \\
\hline $\begin{array}{l}\text { TOTAL-All } \\
\text { products }\end{array}$ & $\begin{array}{l}58 \\
977,7\end{array}$ & $\begin{array}{l}80 \\
974,8\end{array}$ & $6,5 \%$ & $7,8 \%$ & - & - & - \\
\hline $\begin{array}{l}\text { 0201-Meat of } \\
\text { bovine ani- } \\
\text { mals, fresh or } \\
\text { chilled }\end{array}$ & 356,1 & 508,1 & $7,4 \%$ & $10,0 \%$ & 16 & $0,6 \%$ & $9,0 \%$ \\
\hline $\begin{array}{l}\text { 8544- Insu- } \\
\text { lated «incl. } \\
\text { enamelled or } \\
\text { anodised» } \\
\text { wire, cable ... }\end{array}$ & 324,9 & 478,9 & $8,1 \%$ & $13,0 \%$ & 23 & $0,6 \%$ & $5,7 \%$ \\
\hline
\end{tabular}




\begin{tabular}{|c|c|c|c|c|c|c|c|}
\hline $\begin{array}{l}\text { Products } \\
\text { (HS-4) }\end{array}$ & $\begin{array}{c}2014 \\
\text { (€ Million) }\end{array}$ & $\begin{array}{c}2018 \\
(€ \text { Million) }\end{array}$ & $\begin{array}{c}\text { CAGR }_{14-18} \\
(\%)\end{array}$ & $\begin{array}{c}\mathrm{CAGR}_{17-18} \\
(\%)\end{array}$ & $\begin{array}{l}\text { Rank } \\
2018\end{array}$ & $\begin{array}{c}\text { Share } \\
(\%)\end{array}$ & $\begin{array}{l}\text { MFN } \\
\text { Applied } \\
\text { Tariff }\end{array}$ \\
\hline $\begin{array}{l}1201-\text { Soya } \\
\text { beans, } \\
\text { whether or not } \\
\text { broken }\end{array}$ & 300,3 & 435,6 & $7,7 \%$ & $19,2 \%$ & 27 & $0,5 \%$ & $2,5 \%$ \\
\hline $\begin{array}{l}0305 \text { - Fish, fit } \\
\text { for human } \\
\text { consumption, } \\
\text { dried, salted or } \\
\text { in brine; smo- } \\
\text { ked fish, ... }\end{array}$ & 276,3 & 390,3 & $7,2 \%$ & $5,6 \%$ & 32 & $0,5 \%$ & $14,4 \%$ \\
\hline $\begin{array}{l}1905 \text { - Bread, } \\
\text { pastry, cakes, } \\
\text { biscuits and } \\
\text { other bakers' } \\
\text { wares, ... }\end{array}$ & 290,0 & 376,7 & $5,4 \%$ & $6,5 \%$ & 35 & $0,5 \%$ & $77,0 \%$ \\
\hline $\begin{array}{l}9403-\text { Furni- } \\
\text { ture and parts } \\
\text { thereof, n.e.s. }\end{array}$ & 225,5 & 351,1 & $9,3 \%$ & $7,6 \%$ & 43 & $0,4 \%$ & $11,7 \%$ \\
\hline $\begin{array}{l}6204- \\
\text { Women's or } \\
\text { girls' suits, en- } \\
\text { sembles, jack- } \\
\text { ets, blazers, } \\
\text { dresses, skirts, } \\
\text { divided skirts, } \\
\text {... }\end{array}$ & 252,5 & 343,2 & $6,3 \%$ & $7,6 \%$ & 44 & $0,4 \%$ & $18,0 \%$ \\
\hline $\begin{array}{l}8516 \text { - Electric } \\
\text { instantaneous } \\
\text { or storage wa- } \\
\text { ter heaters } \\
\text { and immersion } \\
\text { heaters; ... }\end{array}$ & 181,9 & 280,8 & $9,1 \%$ & $7,3 \%$ & 55 & $0,3 \%$ & $10,4 \%$ \\
\hline $\begin{array}{l}4805-\text { Other } \\
\text { paper and pa- } \\
\text { perboard, un- } \\
\text { coated, in rolls } \\
\text { of a width > } 36 \\
\text { cm or in } \\
\text { square ... }\end{array}$ & 140,9 & 213,4 & $8,7 \%$ & $10,7 \%$ & 80 & $0,3 \%$ & $9,0 \%$ \\
\hline
\end{tabular}


122 José Manuel M. Botelho, Iveta Mietule, Serhii Hushko, Volodymyr Kulishov, Irina Maksymova

Comparative advantages of international trade: the bilateral opportunities

Portugal - Latvia, Portugal - Poland and Portugal - Ukraine

\begin{tabular}{|l|l|l|l|l|l|l|l|}
\hline \hline $\begin{array}{c}\text { Products } \\
\text { (HS-4) }\end{array}$ & $\begin{array}{c}2014 \\
(€ \text { Million) }\end{array}$ & $\begin{array}{c}2018 \\
(€ \text { Million) }\end{array}$ & $\begin{array}{c}\text { CAGR }_{14-18} \\
(\%)\end{array}$ & $\begin{array}{c}\text { CAGR }_{17-18} \\
(\%)\end{array}$ & $\begin{array}{c}\text { Rank } \\
2018\end{array}$ & $\begin{array}{c}\text { Share } \\
(\%)\end{array}$ & $\begin{array}{c}\text { MFN } \\
\text { Applied } \\
\text { Tariff }\end{array}$ \\
\hline $\begin{array}{l}7216-\text { Angles, } \\
\text { shapes and } \\
\text { sections of } \\
\text { iron or non- } \\
\text { alloy steel, } \\
\text { n.e.s. }\end{array}$ & 111,6 & 160,7 & $7,6 \%$ & $10,0 \%$ & 110 & $0,2 \%$ & $12,0 \%$ \\
\hline
\end{tabular}

Source: Feitoria Model developed by authors.

\section{Conclusions}

Internationalization is more of an expansion of business from its home market into foreign markets. The decision to internationalize is one of the strategic decisions that have a fundamental effect on any firm and all its internal and external operations. Even though internationalization has become a very popular thing amongst many companies around the world, it is highly important for every company to consider their motives for going international.

The reason behind going for international market varies from one company to another. However, most firms pursue internationalization because domestic market has become inadequate because of the economies of scale and multiple opportunities that are available in the foreign markets. Most successful executives will always want to try another market after any successful one.

The other good reason for going to a foreign market is to avoid the risk that comes with operating in a single market. Most firms go international with an aim of diversifying risk. An alternative market in a foreign land can be of great help in offsetting negative results of various uncertainties such as economic downturns or political intolerance. Foreign market covers company's loses through the overwhelming performance overseas.

As the companies have varied reasons for pursuing internationalization, every firm that decides to go overseas has a specific objective that it wants to accomplish. This, therefore, means that most businesses would always adopt different modes of entry in specific markets. Since there are numerous reasons for going international, there can never be a right or wrong mode of entry. All the many modes of entry are either right or wrong depending on the reason why the company is going international. 
The Feitoria Model incorporates the Fundamental Concepts and the Economic and Political Concepts that, together, select new markets and therefore indicate the way for companies to follow an internationalization strategy. The application of Feitoria Model is done in two steps. In the first step the Fundamental Concepts are applied, which are the basis of the model; the result is the selection of opportunities for new markets where to export their products. In the second step, the Economic and Political Concepts are applied to the new markets previously chosen in step one; the result is the rejection of economically and politically unstable markets and therefore the acceptance of economically and politically stable markets.

The Economic and Political Concepts are a very important construct that is incorporated in Feitoria Model by the introduction of the dimensions of Governance, Ease of Doing Business, Free Commerce and the Credit Rating. The better the capacity of government to effectively formulate and implement sound policies; and the respect of citizens and the state for the institutions that govern economic and social interactions among them, and the fewer the barriers to the cross-border flow of goods, services, capital and labour, the greater the openness of an economy.

The Competitiveness Concept (MFN Tariff) incorporated in Feitoria Model is a concept which recognizes that lower tariffs may help the country to substantially improve domestic company competitiveness. The increases in trade from tariff elimination are similar in magnitude to those associated with trade facilitation.

In terms of bilateral trade overview between 2014 and 2019, the commercial relations Portugal - Latvia, Latvia - Portugal, Portugal - Poland, Poland Portugal and Ukraine - Portugal increased $12.5 \%, 12 \%, 11.9 \%, 12.1 \%$ and $2.1 \%$ respectively. This is more than the commercial relations with World have grown (Portugal to World 5.5\%, Latvia to World $4.2 \%$, Poland to World $6.6 \%$ and Ukraine to World $-0.2 \%$ ), which underlines the importance of trade between these markets. The commercial relations Portugal - Ukraine increased 2.2\%, but the commercial relations between Portugal and World experienced sharper incline $(5.5 \%)$. This means that there is an opportunity to increase the commercial relations Portugal - Ukraine based on the list of 10 export opportunities published here (table 11) of the total 70 export opportunities for Portugal - Ukraine.

The strategic management model, the Feitoria Model, built to help the economic development of Latvia, Poland, Portugal and Ukraine through the companies of each country, reveals 79 Portugal - Latvia export opportunities, 122 Latvia - Portugal export opportunities, 162 Portugal - Poland export opportunities, 145 Poland - Portugal export opportunities, 70 Portugal - Ukraine export opportunities and 95 Ukraine - Portugal export opportunities. These opportunities are considered as the latest strategic trends and should be explored analyzing the outlook of the country in order to improve the economic development of these countries. 


\section{References}

Azuayi, R. (2016). Internationalization strategies for global companies: A case study of Arla Foods, Denmark. Journal of Accounting \& Marketing, 5(4), 1-9.

Bernini, M., Du, J., \& Love, J. H. (2016). Explaining intermittent exporting: Exit and conditional re-entry in export markets. Journal of International Business Studies, 47(9), 1058-1076.

Botelho, J. \& Kulishov, V. (2018). The Feitoria Prime Market Model: A case study of bilateral trade opportunities Portugal - Poland. Scientific Journal of Polonia University, 27(2), 11-17.

Botelho, J. \& Kulishov, V. (2019). A strategic management model for economic development: The Feitoria Prime Market Model - The competitiveness concept: Most Favoured Nation Tariff (MFN Tariff). The bilateral trade opportunities Portugal - Poland and Portugal - Ukraine. Scientific Journal of Polonia University, 33(2), 56-67.

European Commission. (2020a). Entrepreneurship and small and medium-sized enterprises (SMEs). https://ec.europa.eu/growth/smes_en (accessed 29.12.2020).

European Commission. (2020b). European Commission forecast for Latvia. https://ec.europa.eu/economy_finance/forecasts/2020/summer/ecfin_forec ast_summer_2020_Iv_en.pdf

European Commission. (2020c). European Commission forecast for Poland. https://ec.europa.eu/economy_finance/forecasts/2020/summer/ecfin_forec ast_summer_2020_pl_en.pdf

Estrin, S., Nielsen, B., \& Nielsen, B. (2017). Emerging market multinational companies and internationalization: The role of home country urbanization. Journal of International Management, 23(3), 326-339.

Galvão, O. J. D. A. (2000). The Northeast and multilateral trade negotiations: From GATT to the WTO [in Portuguese]. Fortaleza: BNB.

Kubíčkováa, L., Votoupalováb, M., \& Toulováb, M. (2014). Key motives for internationalization process of small and medium-sized enterprises. Procedia Economics and Finance, 12, 319-328.

Kiefer, L., \& Carter, S. (2005). Global marketing management: Changes. challenges, and new strategies. Oxford University Press.

Love, P., \& Lattimore, R. (2009). International trade. Free, fair and open? OECD Insights. 
Malhotra, N., \& Hinings, C. (2010). An organizational model for understanding internationalization processes. Journal of International Business Studies, 41(2), 330-349.

McDonald, B. (2020). International trade: Commerce among nations. International Monetary Fund. https://www.imf.org/external/pubs/ft/fandd/basics/ trade.htm

Myrdal, G. (1956). An international economy. Harper and Row Publishers.

OECD. (2020). Portugal. OECD Economic Outlook, 2020(1), 230-232. http://www.oecd.org/economy/portugal-economic-snapshot (accessed 02.11.2020).

Prebisch, R. (1959). Commercial policy in the underdeveloped countries. The American economic review, 49(2), 251-273.

Rehm, S., \& Goel, L. (2017). Using information systems to achieve complementarity in SME innovation networks. Information \& Management, 54(4), 438-451.

Ricard, A., Katsuhiko, S., \& Shimizu, M. (2020). Deepening the timing dimension of emerging market multinational companies' internationalization - An exploratory perspective. Journal of International Management, 100799. https://doi.org/10.1016/j.intman.2020.100799

Ricardo, D. (1817). On the principles of political economy and taxation. John Murray.

Standard \& Poor's. (2020). S\&P Global - Ratings. https://www.standardandpoors.com (accessed 29.12.2020).

Topalova, P. (2010). Factor immobility and regional impacts of trade liberalization: Evidence on poverty from India. American Economic Journal: Applied Economics, 2(4), 1-41.

Vaillant, M., \& Ons, A. (2003). Winners and losers in a free trade area between the United States and MERCOSUR. Working Papers, 1403. https://ideas.repec.org/p/ude/wpaper/1403.html

World Bank. (2020a). Doing Business 2020. World Bank. https://www.doi.org/10.1596/978-1-4648-1440-2

World Bank (2020b). Ukraine Overview. Economy. https://www.worldbank.org/ en/country/ukraine/overview\#3 (accessed 02.11.2020).

World Economic Forum. (2013). Enabling trade valuing growth opportunities. http://www3.weforum.org/docs/WEF_SCT_EnablingTrade_Report_2013.pdf

World Integrated Trade Solution. (2020b). Types of tariffs. World Bank https://wits.worldbank.org/wits/wits/witshelp/content/data_retrieval/p/intro/c 2.types_of_tariffs.htm (accessed 29.12.2020). 
126 José Manuel M. Botelho, Iveta Mietule, Serhii Hushko, Volodymyr Kulishov, Irina Maksymova Comparative advantages of international trade: the bilateral opportunities Portugal - Latvia, Portugal - Poland and Portugal - Ukraine

Worldwide Governance Indicators. (2020). WGI 2020 Interactive.
https://info.worldbank.org/governance/wgi/ (accessed 23.11.2020).

Xavier, L. F. (2009). Potential trade versus effective trade: an analysis of the use of relations between the Brazilian Northeast and the European Union [in Portuguese] [Master's Thesis, Federal University of Pernambuco UFPE]. Recife: PIMES/UFPE. https://repositorio.ufpe.br/handle/123456789/4055

Xavier, L. F., Carvalho, R. G., Tenorio Junior, A. J. A., Sousa, E. S., \& Costa, E. C. (2008). Harnessing the relations between Pernambuco and Portugal: an analysis of potential versus actual trade [in Portuguese]. Anais do Fórum BNB de Desenvolvimento e XIII Encontro de Economia Regional. ANPEC/BNB.

Received: November 30, 2020.

Revised: December 8, 2020.

Accepted: January 5, 2020. 